\title{
New findings about the arrangement of internal buildings in La Tène quadrangular enclosures in Bohemia based on the example of the site of Markvartice, East Bohemia
}

\author{
Nové poznatky k organizaci vnitřní zástavby laténských \\ čtyřúhelníkových valových areálů v Čechách \\ na př́ikladu lokality Markvartice, okr. Jičín
}

Tomáš Mangel - Peter Milo - Tomáš Tencer - Tereza Jošková

\begin{abstract}
The article presents the results of geophysical prospection in the quadrangular enclosure of Markvartice, Jičín district, which was carried out in 2018. The obtained data resulted in new findings about the arrangement of internal buildings within sites of this kind known from the territory of Bohemia. The ascertained form of architectural arrangement of the internal space has exact analogies only in identical types of LT C2-D1 enclosures known from the territory of southern Germany. The questions of its particular form, classification possibilities and importance are discussed. The results also confirm the affiliation of the whole enclosure with La Tène sites, the so-called Viereckschanzen, which was repeatedly disputed in the past.

Viereckschanzen - quadrangular enclosure - La Tène period - arrangement of buildings - geophysical survey

Článek prezentuje výsledky geofyzikální prospekce čtyrúhelníkového valového areálu v Markvarticích, okr. Jičín, jež byla realizována v roce 2018. Ziskaná data přinášejí nové poznatky o organizaci vnitřní zástavby těchto areálů známých z českého území. Zjišstěná forma architektonického uspořádání vnitřního prostoru má dosud přesné analogie pouze u identických typů ohrazených areálu známých z období LT C2-D1 $z$ oblasti jižního Německa. Otevřny jsou tak otázky její konkrétní podoby, možností klasifikace i významu. Výsledky zároveň potvrzuji př́slušnost celého ohrazení k laténským areálům tzv. Viereckschanzen, o níz byla v minulosti opakovaně vedena diskuse.
\end{abstract}

Viereckschanzen - čtyrúhelníkový valový areál - doba laténská - organizace zástavby - geofyzikální průzkum

\section{Introduction}

The issue of quadrangular enclosures, the so-called Viereckschanzen, whose existence is usually dated to the LT C2-D1 period, still belongs to current topics in the archaeology of the La Tène period. The main groups of questions pertain in particular to their function (summed up, e.g., in Reichenberger 1993a; Wieland 1995; 1999a; Venclová 2000; 2006; Bollacher 2009, 193-201). Over the recent decades, thanks to new discoveries and thorough analyses, the previously exclusively cultic interpretations have been abandoned. La Tène quadrangular enclosures are now considered rather as residences of members of higher social classes or possibly as polyfunctional facilities combining a number of profane and sacral aspects associated with the existence and identity of the late La Tène elites.

When trying to answer the questions related to the function and importance of these sites, the character of their internal buildings plays an important role, in addition to studies 


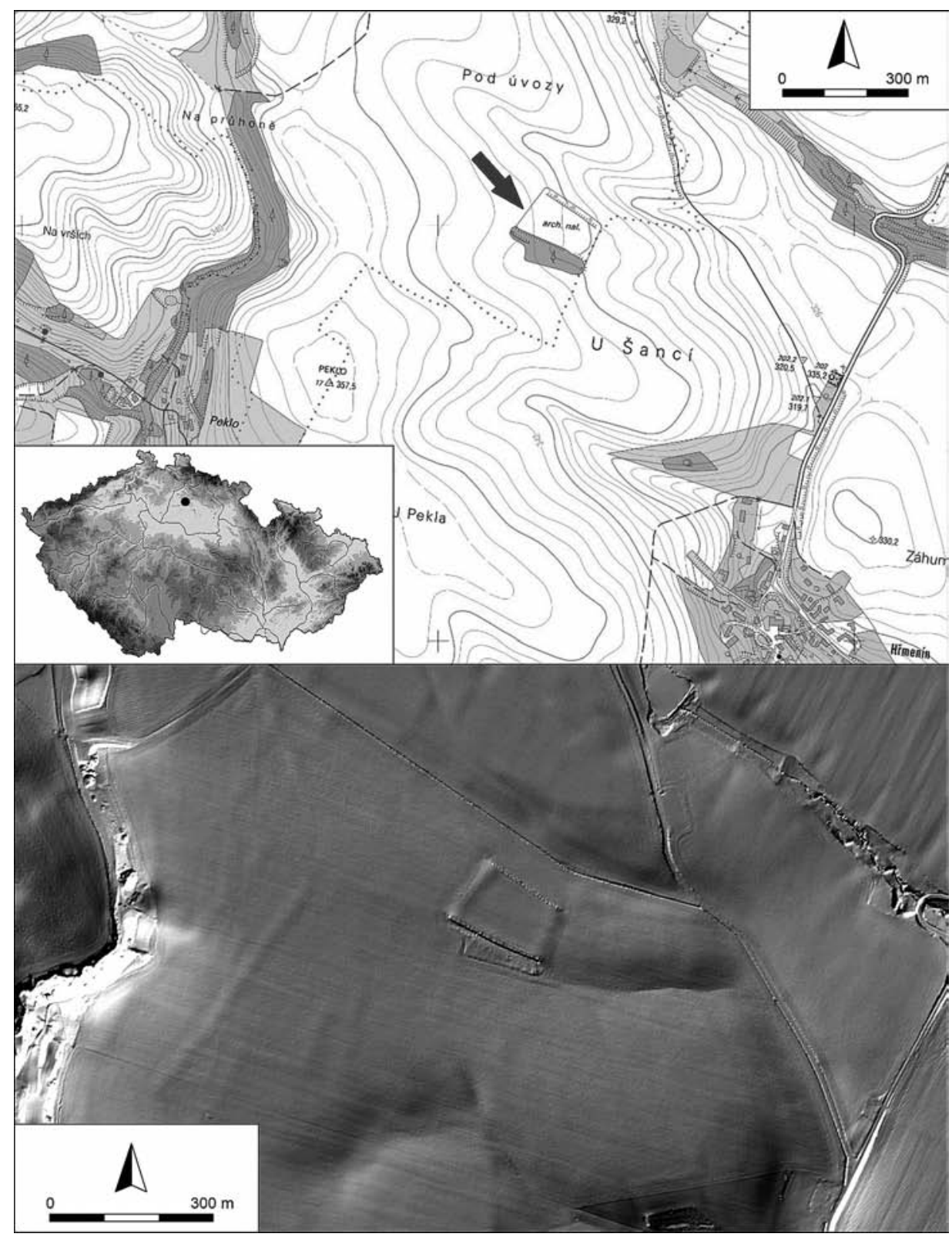

Fig. 1. Markvartice, Jičín district. Location of the enclosure marked with an arrow. Obr. 1. Markvartice, okr. Jičín. Poloha valového areálu označena šipkou.

of the available archaeological material, the placement of the enclosures in the landscape or in the context of the surrounding settlement. In certain problematic cases, field fortifications of modern date can also sometimes be wrongly considered as La Tène enclosures (such as Kokrdov: Šámal 2011; John 2018, 395; Ludéřov: Martínek et al. 2013, 234-235, 
fig. 9; cf. Meduna 1990, 84). In such a situation, a thorough investigation of all the mentioned aspects, along with stratigraphic standpoints, may have a significant importance for the determination of their chronological position. Dating can be problematic especially in the case of enclosures which were only investigated on the basis of non-destructive methods or at a limited extent. It is often not known in such cases whether the situations identified within an enclosure had any chronological links to it (Venclová ed. 2008, 35). The overall form of building development and the identification of its relationship to the enclosure can then play a really crucial role.

A complex understanding of the arrangements of buildings is possible especially thanks to large-scale excavations of entire or at least extensive continuous areas within the enclosures, sometimes even reaching out into their surroundings. Such extensive and costly excavations were sporadically carried out at several sites in southern Germany (such as Beuren: Ambs 2011; Blaufelden: Stork 1999; Bopfingen-Flochberg: Krause - Wieland 1993; Ehningen: Schiek 1985; Nordheim I: Neth 1997; Nordheim II: Neth 2001; Platting-Pankofen: Reichenberger - Schaich 1996; Pocking-Hartkirchen: Schaich 1998; Riedlingen: Bollacher 2009). In the Czech Republic, such methods have not been employed at this type of site yet. Another alternative is the application of geophysical survey methods. Although these methods do not provide complex information about individual identified situations, they are still able to get over basic information about the shape, size and internal structure of buildings within the investigated settlement unit. They do not damage the site in any way and the results are available very quickly. These methods are often employed in all countries where the Viereckschanzen occur (e.g., in Faßbinder 2005; Berghausen 2014). The same is valid for the Czech Republic, where all known and measurable sites of this type were investigated especially thanks to the research activities of $R$. Krivánek $(2013,7)$.

One classic example of a site associated with discussions regarding its chronological and functional position is represented by the enclosure at Markvartice, Jičín district (fig. 1$){ }^{1}$ A new wave of scholarly interest has focused on the site from 2018 onwards, especially in the context of the effort to address some of the so far unanswered questions connected with the time of its origin and the spatial relationships between evidence for La Tène occupation documented both inside and in the outside surroundings. In 2018 the site was subjected to both metal detector and geophysical survey. The aim of this article is to present the most important results of this survey which enable us to draw unambiguous conclusions about the enclosure's date and at the same time provide new findings about internal buildings within La Tène enclosures in the territory of Bohemia.

\section{The current state of knowledge about internal buildings in La Tène quadrangular enclosures in Bohemia and the development of knowledge about the Markvartice enclosure}

The category of La Tène quadrangular enclosures in Bohemia currently includes 10 to 15 sites (summed up in Waldhauser 1992; John 2018). This number is unclear due the fact

\footnotetext{
1 The enclosure is located on land parcel no. 473/2 in the cadastral area of Markvartice, Jičín district. The approximate centre of the enclosed area can be defined by WGS84 coordinates: N $50^{\circ} 25.01863^{\circ}$, E $15^{\circ} 12.20587^{\circ}$.
} 
that some of them were only investigated with the help of non-destructive methods and their dating is therefore not always certain. In addition to this, none of the archaeologically investigated enclosures was entirely or for the larger part excavated - there were just spatially limited test pits, often primarily focusing on the ditch and the earthen wall.

The inner areas of the enclosures were only investigated in sporadic cases. The best known examples include the two-part enclosure of Mšecké Žehrovice, where N. Venclová excavated about $10 \%$ of the inner area in the years 1979 to 1988 (Venclová 1999, 203). The only building which is primarily associated with the enclosure's use is structure $0 / 87$, which was excavated in the northwestern corner of the enclosure's southern square (Venclová 1998, 173-204, fig. 112, 113). The beginnings of this two-phase above-ground structure with maximum dimensions of $1050 \times 1350 \mathrm{~cm}$ are sought in LT C2. Other vestiges of the use of the inner space are represented by a residential unit consisting of two sunken huts, a storage pit and a fire hearth in the northeastern corner of the northern square which was built somewhat later, during LT C2-D1. The other features situated within the enclosed area either precede the construction of the walls or cannot be classified chronologically.

At the turn of the 1970s, partial information about the internal buildings was also obtained by J. Waldhauser at Markvartice. Several dozen smaller test pits and boreholes were measured out and ca. $3 \%$ of the enclosed area were investigated with their help (cf. Waldhauser 1999, 207, Abb. on page 206). The enclosure was roughly dated to LT C2-D1. The best documented structure within the enclosure is an above-ground building with dimensions of $435 \times 610 \mathrm{~cm}$ which was found in its southeastern corner (Waldhauser 1975, 238, Abb. 2). Individual pit-shaped features or smaller clusters of these were also detected along the central parts of the southern and northern wall (Waldhauser 1975, 82; 1989, 49, fig. 10, 11; 1999, 206-208, Abb. 81). Other major discoveries include a sunken house (feature 17) found in the enclosure's northwestern part (Waldhauser 1975, 238) and a La Tène cremation grave delimited by a quadrangular ditch which was situated next to the eastern wall, close to the entrance (Waldhauser 1989, 49, fig. 12).

The list of better-documented remains of internal buildings within quadrangular enclosures can be completed with the site of Třebsko I, whose excavation was carried out by J. Waldhauser and L. Smejtek in 1987 (Waldhauser 1992, 556). The inner area of the enclosure, which is roughly dated to LT C2-D1, was investigated by means of a single test pit (3/87) with dimensions of ca. $80 \times 600 \mathrm{~cm}$ which was dug in the enclosure's western corner (Waldhauser-Smejtek-Nováček 1989, 3-5, Fig. 4). The presence of above-ground architecture in these places is indicated by the remains of three postholes observed in the above-mentioned test pit.

A more colourful picture of internal buildings can be gained from the results of geophysical measurements. Thanks to research activities of R. Křivánek, such measurements were conducted in most La Tène enclosures in the past, and their internal areas were usually surveyed at the maximum possible extent (Foster - Venclová - Krivánek 2004, 258, fig. 4.46; Křviánek 2013; 2014a, 374-376, fig. 2; 2014b, 210-212, fig. 3; Korený et al. 2017, 293-294, fig. 5-7; Hlásek - Mašlová-Křivánek 2018, 221-222, fig. 4, 5). However, opportunities to gain new knowledge were sometimes limited by unfavorable factors, such as unsuitable geological conditions, the presence of vegetation, etc. Individual structures or more complex remains of buildings were only identified in several cases, namely at the sites of Bělčice (Křivánek 2014a, 374-376, fig. 2), Hradiště u Malovic (John 2018, 399), Stožice (Hlásek - Mašlová - Křviánek 2018, 221-222, fig. 4) and Třebsko II (Křivánek 
2013, 5-7, fig. 2). In these cases, larger sunken features and remains of above-ground buildings were almost exclusively found in the corners. The results in general, in accordance with findings from the territory of southern Germany (Rieckhoff 2002, 364-365; Mecking 2018 , 187; Berghausen 2014) seem to prove a low level of use of the enclosures' internal space.

The earliest historical records of the existence of the Markvartice enclosure known as 'Žižkovy valy' (Žižka's ramparts) date from 1714 (Waldhauser 1970-1971, 63). The site later became subject to increased scholarly attention, which also resulted in several opinions on its interpretation which were often expressed with some reservations and a varying degree of persuasiveness (prehistoric or early medieval fortifications: Píč 1909, 377; Pažout 1927, 58; Haken 1974, 20; a Roman military camp: Pažout 1927, 56; Šulc 1966, 12-13; a Swedish encampment: Schaller 1786, 48; Šalda 1955, 79; 1969, 46, 84). Professional archaeologists became increasingly interested in this site during the 1960s. J. Waldhauser conducted a trial excavation there in the years 1969-1970 and 1972 (summed up in Jošková 2016). He recorded several dozen archaeological situations both inside and outside the enclosed area. Some of the test pits were also dug through the enclosure's wall and ditch. Based on the obtained results, J. Waldhauser dated both the enclosure and the situations encountered in its southeast vicinity to the LT C2-D1 period and confirmed its affiliation with the so-called Viereckschanzen (Waldhauser 1970; 1975; 1989; 1992).

Archaeologists got another opportunity to look under the ploughsoil in the enclosure's vicinity in 1978 (for the second time and for the last time until 2019). At that time, an amelioration project was undertaken in the area, which was supervised by archaeologists in just one day: they recorded the presence of a La Tène settlement layer and eighteen more features in the amelioration trenches (Vokolek 1982; Vokolek - Sigl $1978 ; 1979,10)$. Based on these field observations, V. Vokolek concluded that the cultural layer reached under the wall's body which was apparently built later, presumably during the Middle Ages (Budinsky 1986, 123). E. Ulrychová also became a supporter of the idea that the enclosure was of a later date. She believes that the site dates from the period of the Thirty Years' War (Ulrychova 2000; 2010, 27-28, 30). The issues of the chronological classification of the Markvartice enclosure had been repeatedly discussed in the past (e.g. Waldhauser 1970; 1992; 2003), however, its dating to the La Tène period has not been generally accepted yet (cf. Vokolek 1993, 85; Venclová ed. 2008, 35).

During the investigations of the Markvartice enclosure, geophysical methods were applied repeatedly. The first measurements were performed by J. Waldhauser and V. Bárta as early as 1971 and 1972 (Waldhauser 1972a; 1975, 239, note 32). The aim was to locate a well or wells which are relatively common in La Tène enclosures of southern Germany (e.g. Schaich 2001, 140-141). V. Bárta used the electrical resistance method and investigated selected parts of the enclosure representing about $10 \%$ of its surface. The measurements revealed certain anomalies interpreted as pits remaining after extracting materials for the construction of the earthwork (Waldhauser 1972b), besides these no other situations were identified.

Further geophysical investigations at the site were performed by R. Křivánek in 2000 (Křivánek 2014b, 210-212). With magnetometry, he managed to survey an area of 2.4 ha in total (fig. 2). The survey covered the whole inner area of the enclosure with minor extensions on the east and west. The aim was to investigate the already levelled eastern and western sides of the enclosure and together with results from previous archaeological excavations gain overall knowledge about settlement activities in the inner area. The survey did not provide evidence of the intensive settlement activities consisting of larger sunken features. However, it was possible to identify several places with smaller clusters of magnetic anomalies that might indicate the presence of smaller sunken features. The perimeter ditch on the eastern and western sides showed very low magnetic values. It was possible to identify an interruption in the eastern, ploughed-out line of the wall - probably the place where the entrance to the enclosure had been situated. No interruptions of the western, ploughed-out line were noticed. 


\section{The method}

The geophysical survey started in August 2018 was to deepen the knowledge about settlement activities in the vicinity of the enclosure. However, for such research, it is also necessary to get to know the centre whose surroundings are to be investigated. To ensure data compatibility, survey activities in the first phase focused again on the inner part of the enclosure. The current survey was conducted with modern multichannel equipment and covered the area with a higher density of measured points. Such data density enables us to identify spatially smaller and less prominent archaeological features. The goal for the prospection in season 2018 was to identify and locate areas with potential presence of archaeological situations, as well as to define the type and arrangement of archaeological features within the enclosure's inner area. Areas situated outside the enclosure itself were also partly investigated, especially those in its western, eastern, and southeastern vicinity. Due to the large extent of the area planned for prospection and the different modes of agricultural use of the fields it was not possible to conduct the magnetometry survey in the given year. Thus, the tackling of questions associated with the extent and nature of prehistoric use of the area outside the enclosure will only be possible in the future, after the survey is completed. ${ }^{2}$

When trying to answer the questions related to the occurrence of sunken archaeological features and the intensity of human activities in general, magnetometry is the most widely used method of geophysical survey (more on the method, e.g., in Krivánek 2004, 122-124). A simplified definition says that during a magnetic survey, the intensity of the Earth's magnetic field is measured and local anomalies in it can reveal the presence of near-surface structures of various nature. In La Tène enclosures, positive results are to be expected in cases of structures that emerged due to thermoremanent magnetisation, such as fire pits, burned-out layers, destructions of daub, but also hoards or individual iron objects. Sunken features secondarily filled in with darker soils containing organic remains and magnetic minerals can also easily be detected. These include various settlement pits, trenches, sunken huts, and, in ideal cases, also postholes or larger remains of foundations of above-ground buildings.

The area inside the Markvartice enclosure was covered with grass at the time of the survey. Areas in its surroundings are farmed and were overgrown with low vegetation. The geological bedrock of the surveyed areas predominantly consists of loess and loess soils. ${ }^{3}$ This combination provided sufficient contrast for the identification of archaeological situations. The surface was sufficiently dry and hard during the survey. Thus the conditions for prospecting can be considered as optimal. Only the presence of a fire pit established in the central part of the area which is surrounded by stone and wooden elements and several stone monoliths installed along the enclosure's eastern boundary represented certain limitations for the survey. For this reason, the area could not be completely surveyed, as these isolated parts had to be left out.

Concerning to the fact that the ground is flat, and the area is free of trees, we decided to use a LEA MAX fluxgate magnetometer with FEREX CON 650 probes, which is suitable for large-scale archaeogeophysical surveys. The device is designed as a gradiometer for measuring the vertical gradient of the local magnetic field and can record the magnetic field intensity values with a precision of $0.2 \mathrm{nT} / \mathrm{m}$. The horizontal distance between the ten probes mounted on the device is $0.5 \mathrm{~m}$. The vertical distance between the two sensors in each probe is $0.65 \mathrm{~m}$. The areas were geophysical surveyed directly, with the use of RTK GNSS (Real Time Kinematic Global Navigation Satellite Systems). The magnetometer was used in

\footnotetext{
${ }^{2}$ Measurements in other areas (27 ha in total) continued in the summer of 2019. The completion of the whole project is planned for 2021.

${ }^{3}$ See Geoscientific maps (Geovědní mapy) $1: 50000$ [online]. ČÚZK @. [quoted as of $20^{\text {th }}$ December 2019]. Available from: https://mapy.geology.cz/geocr50/
} 


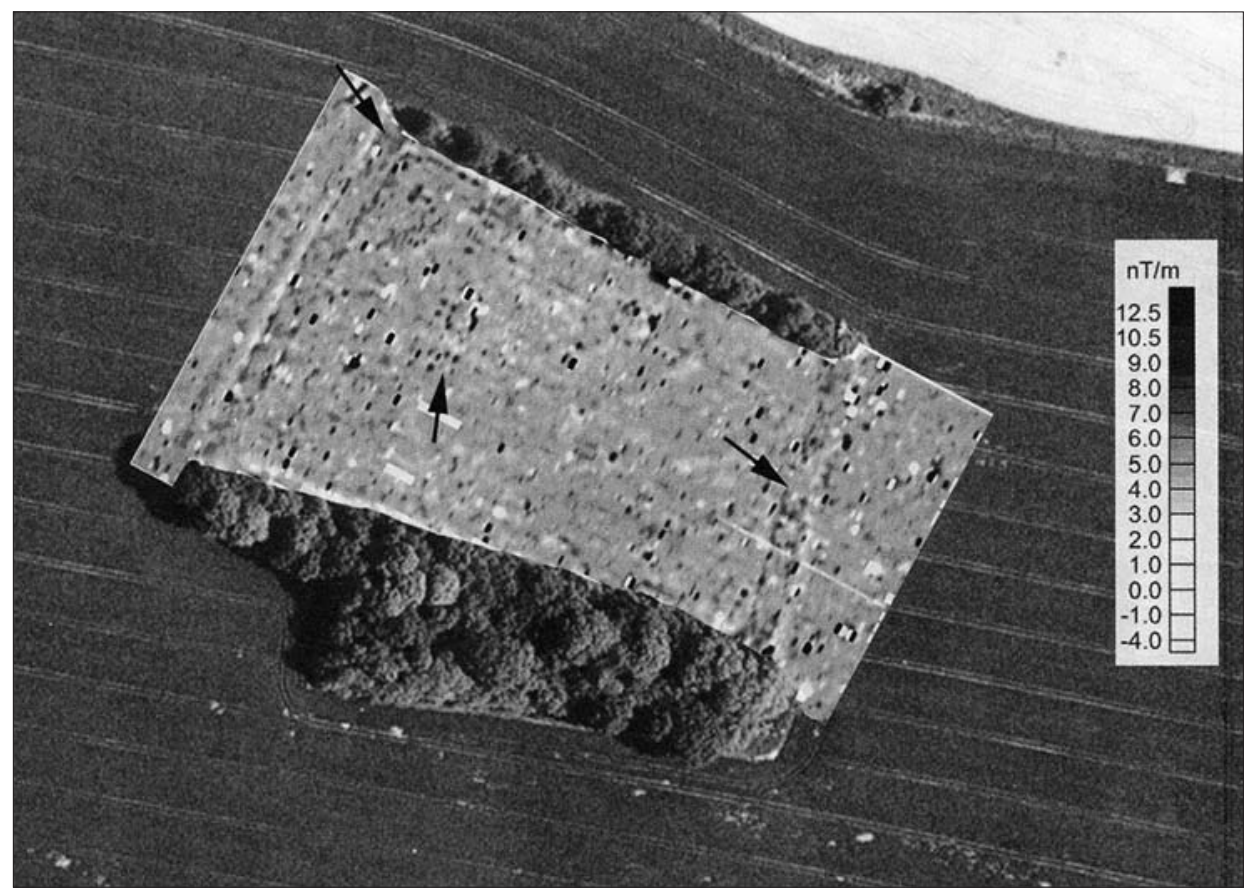

Fig. 2. Markvartice, Jičín district. Results of geophysical measurements conducted within the enclosure by R. Křivánek in 2000. After Křivánek 2014b, fig. 3.

Obr. 2. Markvartice, okr. Jičín. Výsledky geofyzikálního měření provedeného uvnitř valového areálu v roce 2000 R. Křivánkem. Podle Křivánek 2014b, obr. 3.

the ATV mode (a non-magnetic cart pulled by a quad bike). The total size of the area surveyed in 2018 was 10.9 ha. However, in this paper, only the results which are relevant for the area inside the enclosure with minor overlaps in the northeastern and southwestern direction are discussed. The area in question is 1.6 ha (fig. 3).

\section{The results}

\section{The enclosure}

The northern and southern lines of the enclosure are well visible in the terrain, but they are densely overgrown with vegetation, so they were not subject to prospecting. In contrast, the western and eastern wall lines were levelled in the past (Waldhauser 1970-1971, 63; 1978) and are only discernible as less prominent areas of raised ground today. In such places, the survey recorded the presence of linear structures that enable a reconstruction of the original course of former walls and ditches (figs. 3-5). The fortification's western part is better preserved. The ditch showed as a straight, linear, about $5 \mathrm{~m}$ wide structure without any interruption. On both sides, it was lined with thin bands of positive magnetic values, while the ditch's fill shows negative values. Approximately $3 \mathrm{~m}$ from the inner side of the ditch, remains of the wall's body can be observed. The magnetic values of the wall's core do not noticeably differ from those of its surroundings. It manifested in the geophysical 
data as thin lineaments with slightly positive magnetic values lining its edges. The wall's width can be estimated at approximately $4.5 \mathrm{~m}$. The fortification in the eastern part is significantly damaged by the latter activities. However, based on the obtained data, its course can only be reconstructed. We assume that fortification at the eastern side was similar to the western side of the enclosed area.

Surveys of enclosures often include attempts to identify the entrances to the inner area. Unfortunately, the difficult conditions and the bad state of preservation of the enclosure in places along the original eastern side do not enable us to draw unambiguous conclusions in this respect. There are several interruptions in the wall line and none of them can be explicitly designated as the primary entrance to the enclosed area. However, thanks to earlier observations, its location can be sought approximately in the middle of the eastern wall (fig. 2; Waldhauser 1970-1971, 63, fig. 2; Krivánek 2014b, 211, fig. 3). The absence of the interruption of the earthwork or ditch on the western side supports this hypothesis. ${ }^{4}$

\section{The inner area}

The geophysical data contains evidence for the presence of both archaeological features and recent interventions (figs. 3-5). The later are probably mainly earlier archaeological test pits and trenches associated especially with J. Waldhauser's excavations. These appeared as negative anomalies. However not all of the test pits were detected (cf. e.g. Waldhauser 1999, Abb. 81). The majority of identified trenches are situated in the area near the east wall. Structures of recent date also include numerous bipolar anomalies which are usually represented by various iron objects. The occurrence of these anomalies can be observed throughout the whole surveyed area, but they do not seem to form any distinct clusters. These anomalies are, as a rule, a consequence of recent farming activities (fertilization, ploughing, etc.) and do not have any relationship to earlier anthropogenic activities. However, the archaeological nature of some of them cannot be ruled out with certainty. They may theoretically also include artefacts connected with the site's use during the Iron Age or later historic periods.

In addition to recent structures, approximately 70 magnetic anomalies which might indicate archaeological situations were identified. The sheer majority of them manifest as dot anomalies and can, therefore, be interpreted as smaller features, such as postholes. Most attention should be paid to their concentrations which form four separate structures. Judging from the character of these structures, these can be interpreted as evidence of above-ground post buildings. Their exact shape, function or dating cannot be deduced from geophysical data. It is only possible to make some preliminary comments on the dimensions of individual features. Structure A is located in the central part of the enclosure's western half (fig. 5: A). The presence of archaeological situations there was already indicated by the measurements conducted by R. Křivánek, who noted a cluster of uninterpretable smallsized anomalies in these places (Křvánek 2014b, 211, fig. 3). The magnetic survey in

\footnotetext{
${ }^{4}$ It is apparent from the cadastral map that a farm track used to lead into the inner area and entered it approximately in the middle of the west side (Jansová 1968, 483, Abb. 8). As late as the late 1960s, an interruption of the ditch was still visible there (the wall itself was probably levelled in the $18^{\text {th }}$ century). The ditch is locally filled in, which was probably done recently (Waldhauser 1970-1971, 63, fig. 1, 2). The fact that this is a secondary modification is also confirmed by the results of our geophysical measurements.
} 


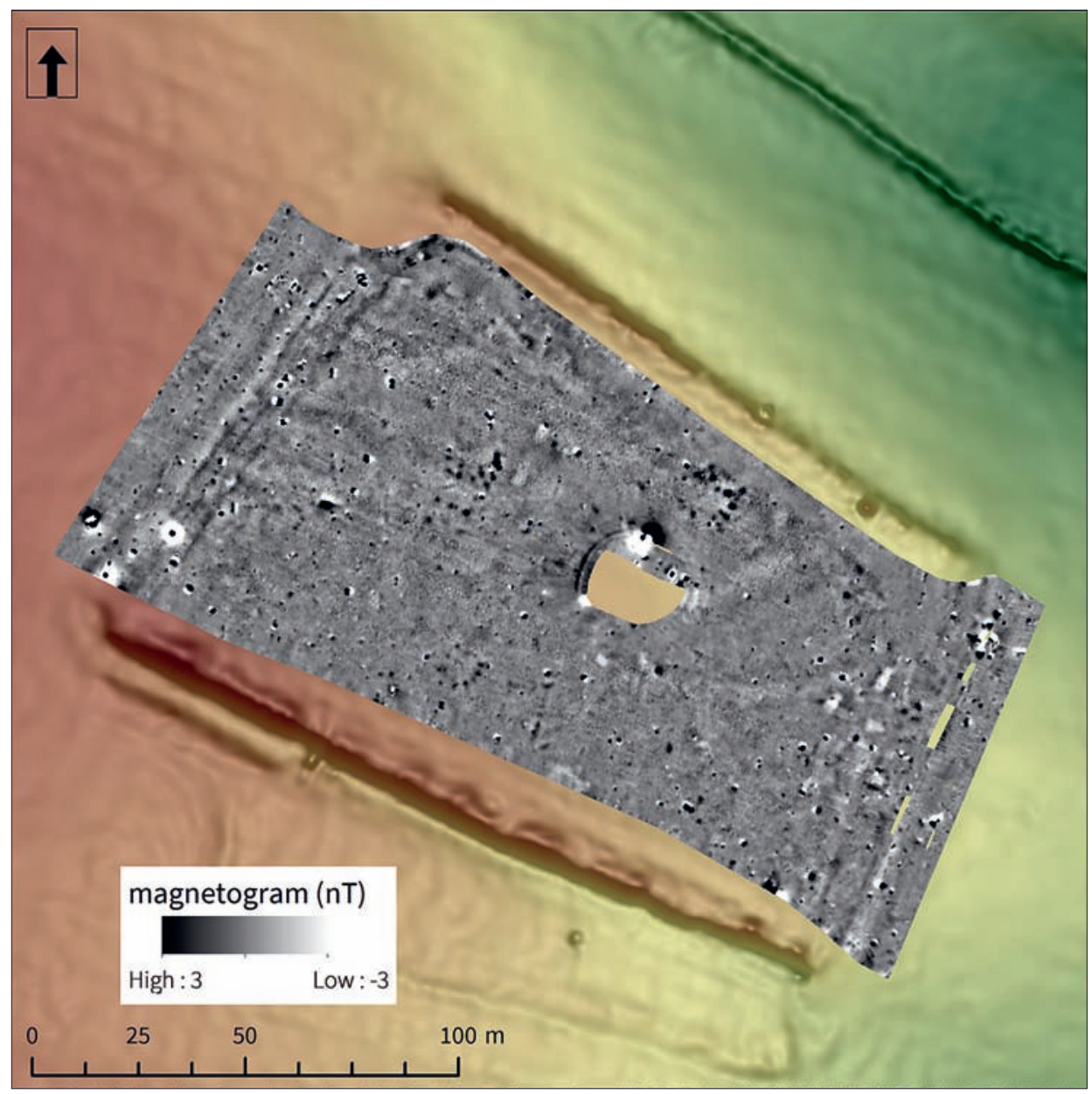

Fig. 3. Markvartice, Jičín district. Magnetogram from the 2018 measurement campaign. Obr. 3. Markvartice, okr. Jičín. Magnetogram z měření provedeného v roce 2018.

question revealed thirteen potential larger postholes which form an irregular layout with dimensions of ca. $16.3 \times 11.4 \mathrm{~m},{ }^{5}$ whose longer axis was oriented northeast-southwest. Structure B is situated near the north wall, approximately in its central part (fig. 5: B). A group of ten to fifteen pits was detected there which form an approximately square ground plan with dimensions of ca. $12 \times 11 \mathrm{~m}$, whose longer axis was oriented northwest-southeast, parallel to the line of the wall. However, it is necessary to note that one of the earlier archaeological test pits was situated in this area (Waldhauser 1970-1971, 82-84, fig. 10; 1989,49 , fig. 11) so it is questionable to what extent these are undisturbed archaeological

\footnotetext{
5 The determination of the lengths and widths of the individual structures is based on maximum distances between the centres of outer geomagnetic anomalies in their ground plans.
} 


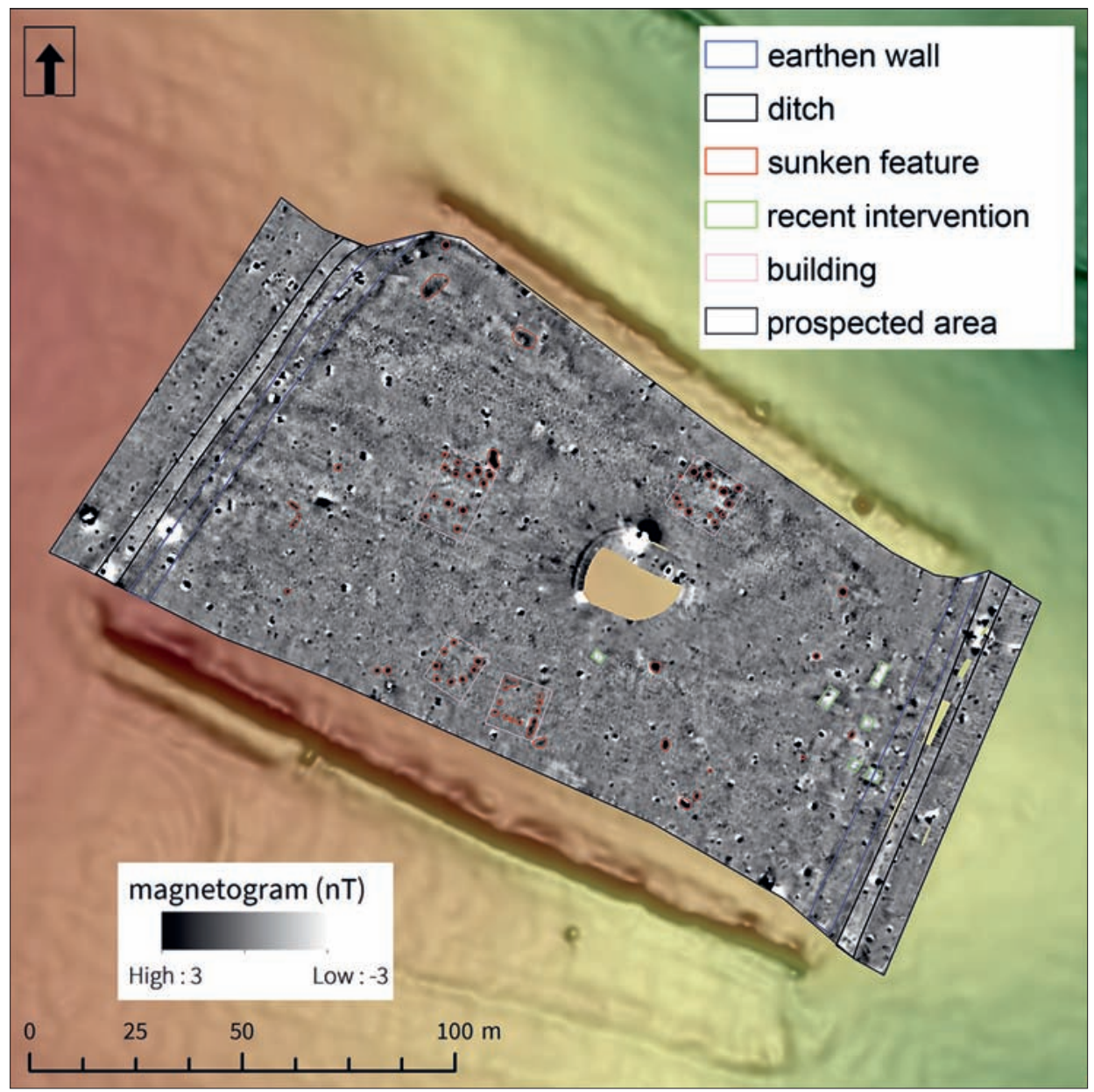

Fig. 4. Markvartice, Jičín district. Interpretation of measured magnetic anomalies plotted on the original magnetogram showing the results of measurements conducted in 2018.

Obr. 4. Markvartice, okr. Jičín. Interpretace naměřených magnetických anomálií zanesená do originálního magnetogramu z měření provedeného $v$ roce 2018.

situations. Structures C and D were discovered at the south wall, approximately in its centre. Structure C consists of eight to ten postholes which form a rectangular ground plan whose south side is narrowed and which has dimensions of ca. $10 \times 9 \mathrm{~m}$ (fig. 5: C). Structure D is only vaguely discernible in the geophysical data (fig. 5: D). Its square ground plan has dimensions of ca. $9 \times 9 \mathrm{~m}$ and consists of a trench and/or several smaller postholes situated next to each other. Both structures are oriented parallel to the nearby earthen wall. The remaining ca. 20 anomalies are generally scattered over the enclosure's whole inner area or only form small groupings which cannot be interpreted without further clues.

An exception present in the obtained data is represented by two larger anomalies identified in the NW corner of the enclosed area. The first anomaly (fig. 5: E) has dimensions 


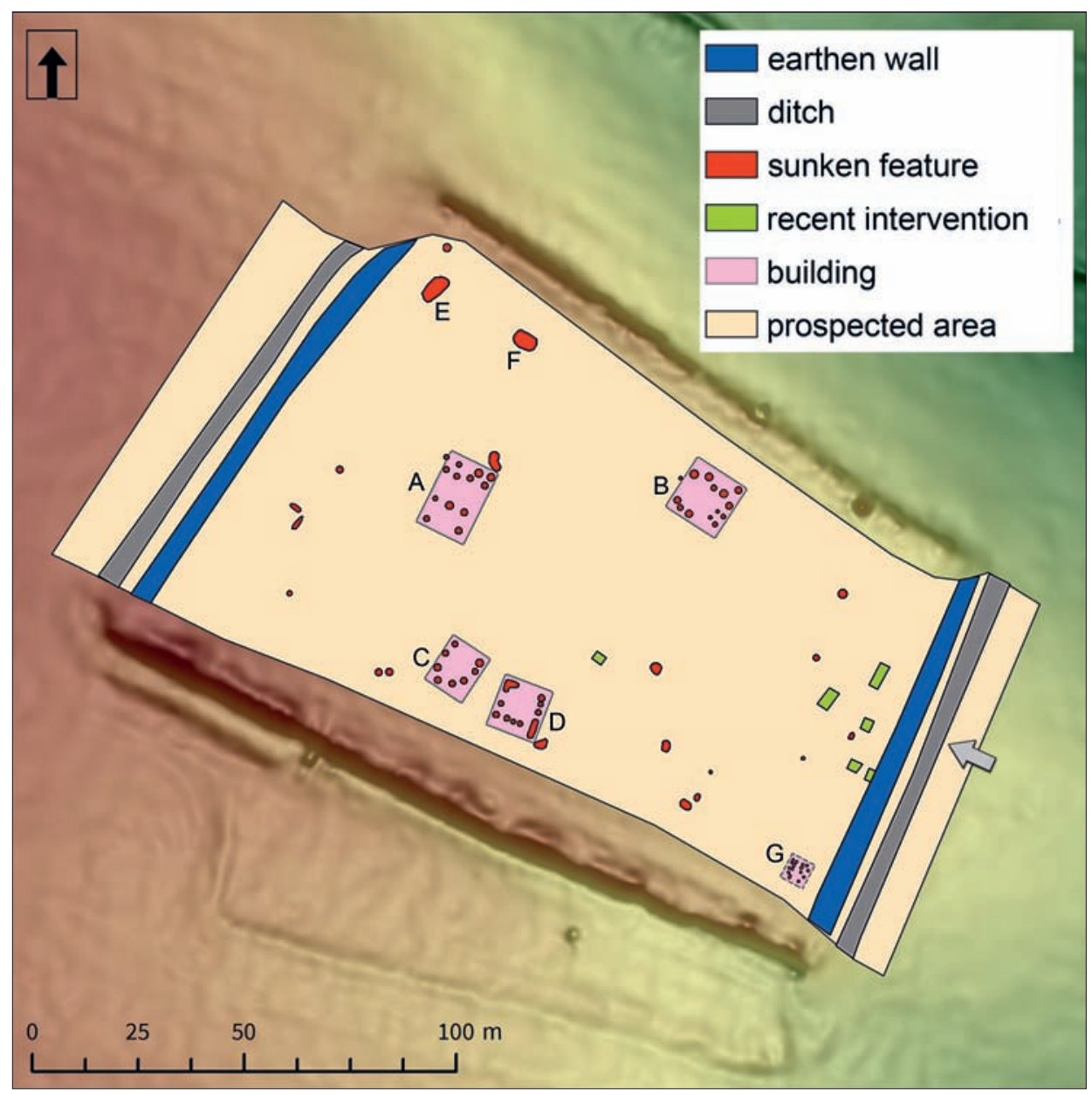

Fig. 5. Markvartice, Jičín district. General interpretation of the magnetogram showing the results of measurements conducted in 2018 in the context of selected earlier findings. A-D - above-ground buildings detected through geophysics in 2018; E, F-sunken huts (?) detected through geophysics in 2018; G - approximate location of an above-ground structure unearthed during J. Waldhauser's excavation in the years 1969-1970. The arrow marks the original location of the entrance in the currently ploughed out eastern line of walls.

Obr. 5. Markvartice, okr. Jičín. Celková interpretace magnetogramu z měření provedeného v roce 2018 v kontextu vybraných starších zjištění. A-D - povrchové stavby zachycené prostřednictvím geofyziky v roce 2018; E, F- polozemnice (?) zachycené prostřednictvím geofyziky v roce 2018; G - přibližná lokalizace povrchové stavby odkryté v rámci výzkumu J. Waldhausera realizovaném v letech 1969-1970. Šipka označuje původní polohu vstupu v dnes rozorané východní valové linii.

of ca. $6.5 \times 3 \mathrm{~m}$ and it's longer axis is oriented northeast-southwest. The other, somewhat smaller structure is oriented perpendicular to the previous one and situated at a distance of ca. $20 \mathrm{~m}$ from it (fig. 5: F). Its dimensions can be estimated at ca. $5 \times 3 \mathrm{~m}$. The interpretation of both structures is not unambiguous, but according to their shapes and dimensions, these may have been sunken huts. 


\section{Discussion}

If we want to assess the appearance and importance of buildings within the Markvartice enclosure, it is necessary to consider the fact that their reconstruction is mainly based on geophysical measurements which can further be supplemented with certain significant, but spatially limited findings from earlier trial excavations. The recorded form of individual elements and their general arrangement are not necessarily complete. Still, the obtained results enable a comparison with numerous building structures abundantly documented within quadrangular enclosures in southern Germany.

The most distinctive part of the identified above-ground architecture is represented by structure A which was identified approximately in the centre of the enclosed area (fig. 5). Its ground plan and placement conform to large rectangular buildings commonly documented within southern German enclosures (Wieland 1999b, 35, Abb. 8; Schaich 2001, 136-138, Abb. 15; Donat 2006, 150-155). These are usually post buildings whose ground plans consist of different numbers of variously arranged foundation pits. The ground plans of these buildings usually reach relatively large dimensions and commonly cover an area of over $100 \mathrm{~m}^{2}$ (Mecking 2018, 186, Abb. 5, Tab. 1). Even structures with a size of more than $300 \mathrm{~m}^{2}$ are not uncommon (e.g. Mengen-Ennetach: Wieland-von der Osten-Woldenburg - Wahl 1999, 129; Nordheim I, II: Auer et al. 2018, 114, Abb. 2; Pfaffenhausen: Faßbinder-Irlinger 2005, Abb. 81; Sallach 'groß': Hoffmann 2007, 121-122, Abb. 62). The Markvartice structure seems to belong to spatially distinctive features of this type, its size being at least $185 \mathrm{~m}^{2}$. From the viewpoint of their placement within the enclosure, the mentioned buildings can be found in various positions (in the enclosure's corners, next to the earthen wall or in the inner area). However, an important place among them occupy so-called Zentralbauten or Hauptbauten, i.e. structures placed, similarly to Markvartice, approximately in the line of one the enclosure's axes (Schaich 2001, 127; Bollacher 2009, 97).

Another characteristic element known from southern German enclosures are larger quadratic buildings (Schaich 2001, 132-133, Abb. 12). The criteria for such a classification can be fulfilled by structures B and D, whereas the situation seems to be less obvious in the first case. We compared the results of the 2018 measurements to plans of J. Waldhauser's excavations (Waldhauser 1999, Abb. 81) and it seems that some parts of both structures had partially been unearthed in test pits dug at the turn of the $1960 \mathrm{~s}^{6}{ }^{6}$ Generally speaking, analogies to them can be found, for example, in the ground plans of buildings at the sites of Nordheim I (Neth 1997, 81, Abb. 42: A), Riedlingen (Bollacher 2009, 70-73, Abb. 44-48), Platting-Pankofen (Reichenberger - Schaich 1996, 108-110, Abb. 12, 16) or ArnstorfWiedmais (Reichenberger 1986, 90, Abb. 49: D), but a more exact classification from the viewpoint of their structural solution is not possible on the basis of the available data.

The appearance of structure $\mathrm{C}$ can only generally be classified, too. The discovered traces indicate its affiliation with so-called one-nave buildings, although these are usually somewhat smaller, normally about 2.5-6.5 × 4-8.5 m (Schaich 2001, 132, Abb. 11; Laurelut-Tegel-Vanmorkerke 2009, 79-83, Abb. 5). When it comes to the ground plan, the

\footnotetext{
6 A concentration of several smaller and larger pit-shaped features was excavated in the proximity of the north wall (Waldhauser 1970-1971, 82-83, fig. 2: 5, 6, fig. 10; 1975, 238; 1989, fig. 10), of which at least some are connected with the construction of structure B. A circular feature (one of the larger postholes?) which was identified through trial excavation near the south wall can be associated with structure D (cf. Waldhauser 1999, Abb. 81: 7).
} 
best analogy is represented by structure D from the enclosure of Bopfingen-Flochberg, the dimensions are, however, closer to structure $\mathrm{C}$ discovered at the same site (Krause Wieland 1993, 78-80, Abb. 11). The ground plans of such one-nave buildings which most often consist of six postholes are usually considered as remains of granaries, although a different type of use for agricultural, residential or other purposes is not completely ruled out either. In certain cases, additional pairs of offset holes which are usually rather small were observed near these structure. These are usually interpreted, although not without some reservations, as remains of entrances (Köhler 1992, 35; Laurelut-Tegel-Vanmorkerke 2009; critical comments Donat 2006, 148-150, Tab. 5). In the case of structure C from Markvartice, a pair of small holes situated near each other along the south side of the ground plan seem to conform to such a definition. The question of how such a potential entrance was oriented remains open, as it would face the wall and not the empty space in the enclosure's central area. However, it is necessary to state that this is not an isolated case. A similar orientation of an offset pair of small holes was observed, e.g., near a similarly oriented structure unearthed in the northeastern corner of the enclosure at the site of Donnersberg (Wieland 1999c). There is another possible explanation - it might have been a building with a less common ground plan including an apse (cf. Mecking 2017, 129, Abb. 6).

The last known part of above-ground architecture is structure $\mathrm{G}$, which was excavated in the enclosure's southeastern corner at the turn of the 1960s (Waldhauser 1975, 238, Abb. 2; 1999, 207, Abb. 81: 5, 82). It is an incompletely preserved ground plan of a twophase post building with dimensions of $610 \times 435 \mathrm{~cm}$ (fig. 6). Judging from the arrangement of the postholes, such a building is traditionally designated as a so-called 'Umgangsbau' or 'Umgangstempel' (cf. Reichenberger 1995; Donat 2006, 138-143). In A. Mecking's neutral concept (Mecking 2017), it belongs to buildings with double rows of structural elements along the perimeter (Doppelreihiger Pfostenbau). This type of above-ground architecture is relatively common in southern Germany - it does not only occur within La Tène enclosures but also in the oppida and at open settlements (Schubert 1995; Möslein 2003; Leicht 2013, 58-60, Abb. 19, 20). Structure G is, however, relatively small in comparison with its numerous southern German equivalents (Mecking 2017, 129-131, Abb. 2). ${ }^{7}$

The notion of internal buildings is complemented by two anomalies of larger dimensions situated in the enclosure's northwestern corner (fig. 5: E, F). Their dimensions and shape seem to indicate that these may have been sunken huts. When we compare the magnetogram and a plan showing the distribution of earlier test pits, it is highly likely that structure F is identical with sunken hut 17 excavated by J. Waldhauser $(1975,238$, Abb. 2-3, Taf. II, III: 1-7; 1999, 207, fig. 81: 11), which in addition to LT C2-D1 artefacts also contained several finds characteristic of LT C1. It can generally be said that sunken houses are only rarely documented among buildings within La Tène quadrangular enclosures (Mecking 2017, 135-136). Some of them were apparently not contemporaneous with the construction and primary use of the enclosures. Sunken hut no. 4 from Riedlingen (Bollacher 2009, 50-51, Abb. 7, 29) or feature 558 from Beuren (Ambs 2011, 77, Abb. 100) which were partly overlapped by the bases of the walls can be mentioned as an example.

\footnotetext{
7 Structure G at Markvartice covers an area of ca. $26.5 \mathrm{~m}^{2}$. According to A. Mecking $(2017,125,129)$, the smallest building of this type known from the environment of southern German enclosures takes up an area of $37.42 \mathrm{~m}^{2}$. Nevertheless, the sizes of the majority of these buildings range between 100 and $200 \mathrm{~m}^{2}$.
} 
In contrast to this, a cluster of sunken huts documented in the northern part of the enclosure at Mšecké Žehrovice is probably linked to secondary construction activities which took place with a certain time lag from the construction of the earthen walls (Venclova 1998, 199, fig. 112). In several other cases, a primary connection between sunken huts and enclosures cannot be ruled out. It is quite remarkable that the sunken huts in these cases were always, with the exception of sunken hut 5 at Riedlingen (Bollacher 2009, 51-54, Abb. 7, 30), visually overshadowed. When someone looked from the entrance, the view of them was blocked by above-ground buildings (Beuren, feature 558: Ambs 2011, 53-54, Abb. 64, Beilage V.1; Nordheim I, structures D and E: Neth 1997, 82, Abb. 42: D, E). The relationship between the sunken features at Markvartice and the enclosure itself still remains an open question. The magnetogram seems to indicate that the orientation of both anomalies situated behind the above ground-buildings follows the course of the fortification lines, however, the spectrum of finds from sunken hut 17 does not rule out the possibility of its use as early as the transition from LT C1 to LT C2, that is, some time before the construction of the enclosure. In such a case, their orientation could be linked, e.g., to the presence of an undocumented form of a lighter enclosure which had preceded the construction of earthen walls. Similar situations are also known from several other sites (e.g. Beuren: Ambs 2011, 71, Abb. 92; Holzhausen: Schwarz 1960, 28-30, Abb. 16: 1; Mšecké Žehrovice: Venclová 1998, 198, fig. 112). The remnant of a narrow broken line of unclear purpose, perhaps a ditch or trench, detected in the enclosure's NW corner (fig. 2; Krivánek 2014b, 211, fig. 3), could theoretically be linked to such an alternative.

The last and at the same time quite exceptional structure situated within the inner area of the Markvartice enclosure is a La Tène grave surrounded by a quadratic trench which was investigated by J. Waldhauser in the immediate vicinity of the entrance in the east wall line in 1970 (Waldhauser 1975, 238, Abb. 1: 8; 1989, 49, fig. 12). It should be discussed in detail. Although the recovered grave goods do not allow its precise dating, certain clues are provided by the stratigraphic situation. With regard to the fact that the grave pit itself and partly also the delimiting trench were located under the body of the (destroyed?) wall, it is obvious that the construction of the funerary monument must have preceded the construction of the enclosure's wall (Reichenberger 1993b, 209; Venclová 1998, 211). Such an explanation also conforms to the generally known fact that ritual burying in Central European La Tène necropolises ceased at the close of LT C1, which is chronologically different from the period of occurrence of quadrangular enclosures in LT C2-D1 (Waldhauser 1979, 144-150; cf. Stöckli 2018, Abb. 10B). The discussed grave, along with sunken hut 17 , could then bear witness to activities preceding the construction of the enclosure's walls. However, this hypothesis should still be verified in the future.

It is obvious that especially above-ground architecture, which represents a dominant portion not only at Markvartice but also in other quadrangular enclosures, is very important for understanding the importance of the Markvartice site. All elements of above-ground architecture at Markvartice seem to respect, or rather follow the course of the wall lines (fig. 5). It is therefore almost certain that the wall and the buildings were contemporaneous, at least for some time. Their general arrangement resembles a horseshoe-shaped structure which is open towards the east wall in which the original entrance to the walled area must have been situated. A similar arrangement of the inner space in several southern German La Tène enclosures was first noted by S. Rieckhoff (2002, 364-365, Abb. 3). In her understanding, such a construction scheme is a characteristic of one of the socioeconomic cate- 


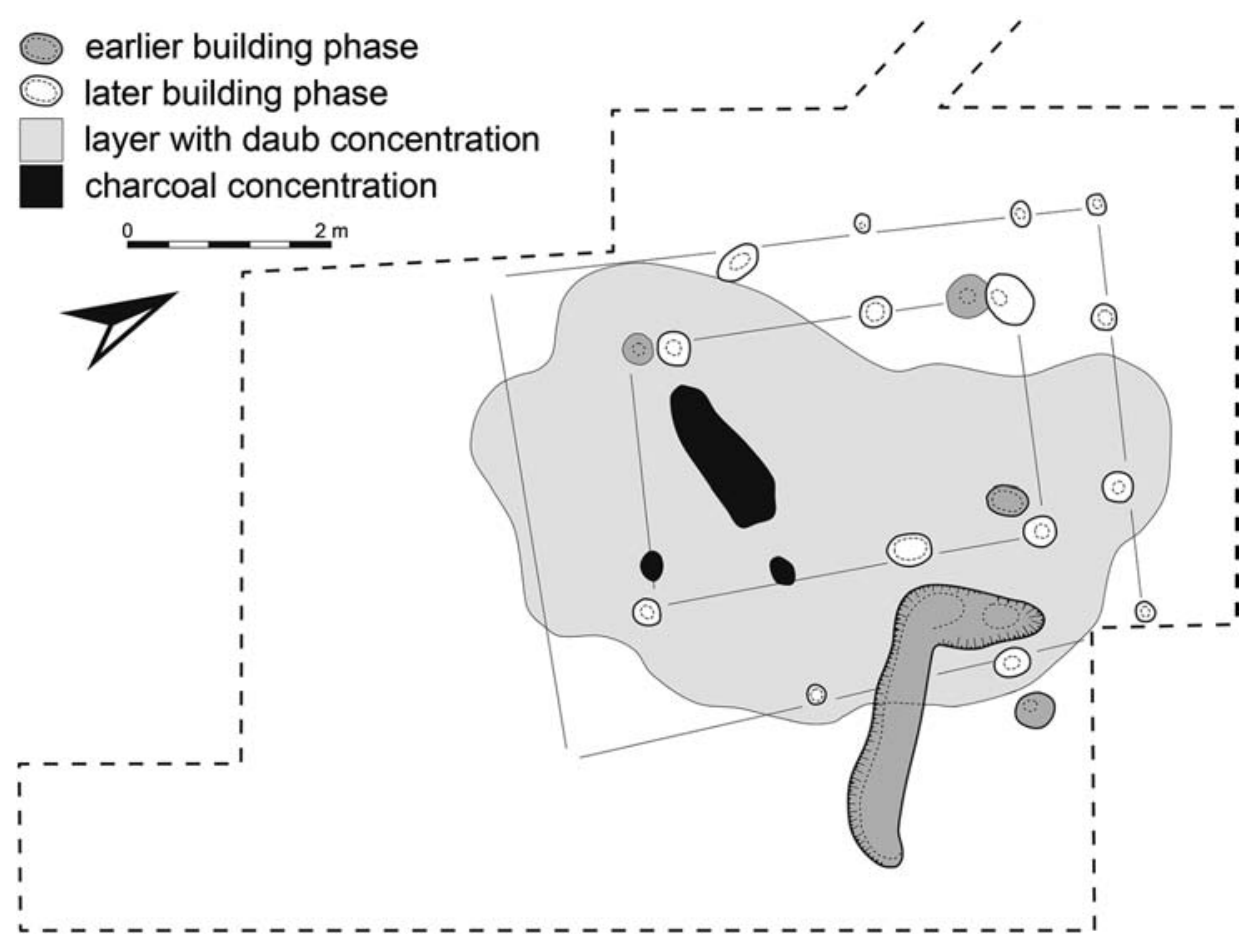

Fig. 6. Markvartice, jičín district. Ground plan of above-ground structure G excavated in the years 1969 and 1970 in the enclosure's southeastern corner. After Waldhauser 1975, Abb. 2-3, modified. Digitised by L. Čiháčková.

Obr. 6. Markvartice, okr. Jičín. Půdorys povrchové stavby G prozkoumané v letech 1969 a 1970 v jihovýchodním nároží valového areálu. Podle Waldhauser 1975, Abb. 2-3, upraveno.

gories of enclosures which are known as the Riedlingen type. ${ }^{8} \mathrm{~A}$ more detailed definition of this scheme was only presented by Ch. Bollacher (2009, 97, Abb. 65, 66). A basic characteristic of it is the axial symmetry in the arrangement of buildings whose axis is represented by a connecting line between the entrance and the significant building standing on the opposite side of the inner area. Other smaller structures placed in the corners of the entrance side together with the significant building then form a triangle. The above basic scheme can be complemented by other building structures placed along the enclosure's perimeter. However, it results from general analysis of the current state of research on buildings in enclosures that this ideal arrangement is respected in a limited number of cases only (Mecking 2017, 137, Abb. 8; 2018, 186). Classic examples of sites conforming to the definition of the Riedlingen type (fig. 7: 1-4, 8) certainly include the sites of Riedlingen (Bollacher 2009), Ehningen (Schiek 1985), Bopfingen-Flochberg (Krause - Wieland 1993), Pocking-Hardkirchen (Schaich 1998) and Maxing (Schaich 2002, 336, Abb. 5).

\footnotetext{
${ }^{8}$ Another category whose characteristic attribute is scattered development was designated as the Wiedmais type by S. Rieckhoff (2002, 365, Abb. 3). However, most scholars still do not accept this type, due to its definition based only on its difference from the Riedlingen type, which results in great variability (cf. Bollacher 2009, 97-98; Mecking 2017, 137).
} 

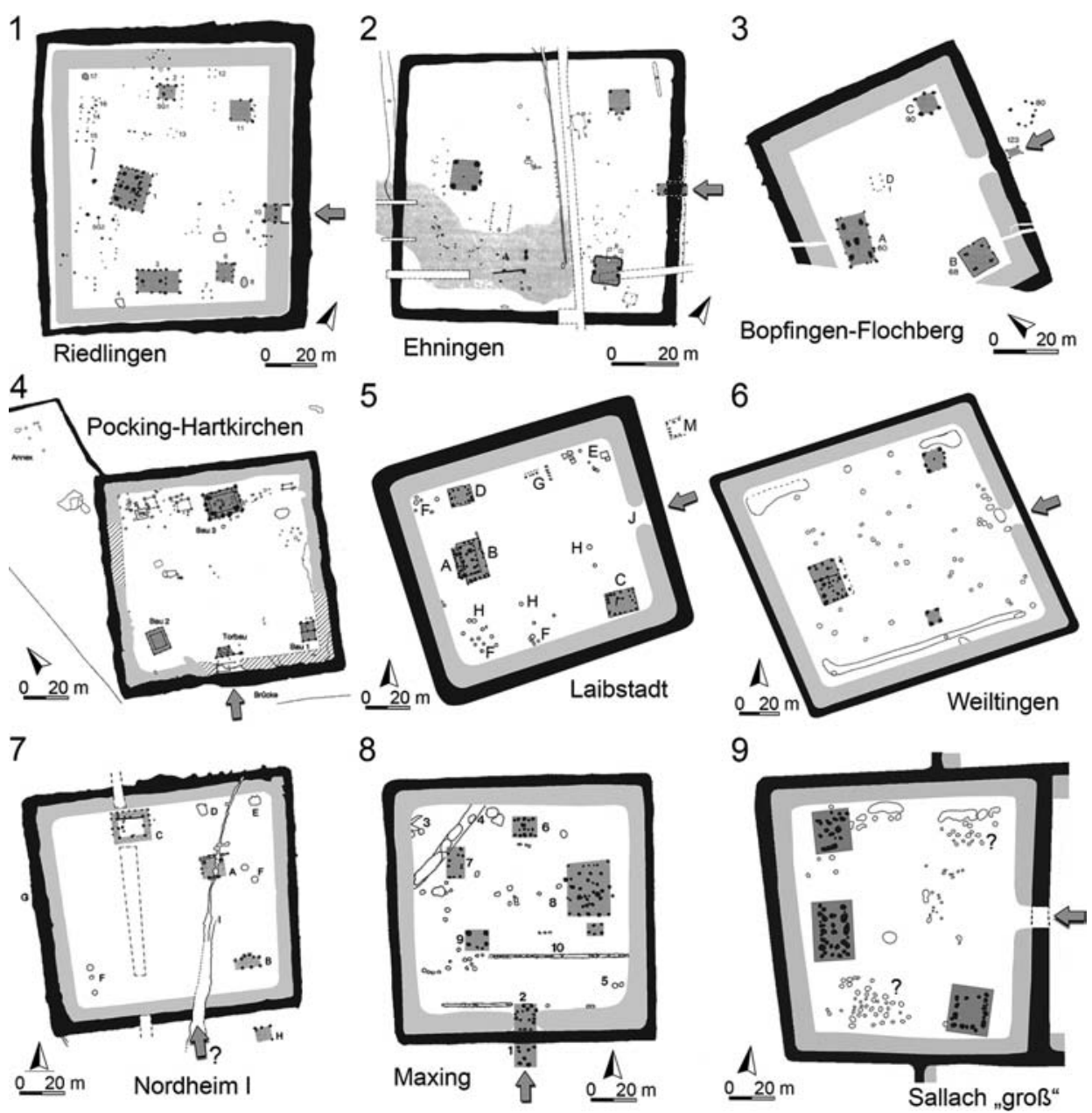

Fig. 7. Examples of La Tène quadrangular enclosures with a significant building situated opposite the entrance in southern Germany. The arrow marks the entrance to the enclosure. 1-4 - after Bollacher 2009, Abb. 65; 5 - after Berghausen 2010, Abb. 111; 6 - after Berghausen 2014, Abb. A8, 9; 7 - after Neth 1997, Abb. 42; Auer et al. 2018, Abb. 2; 8 - after Faßbinder - Irlinger 2000, Abb. 34; Schaich 2002, Abb. 5; 9 - after Hoffmann 2007, Abb. 62. All modified.

Obr. 7. Příklady laténských čtyřúhelníkových valových areálů z jižního Německa s význačnou stavbou umístěnou naproti vstupu.

Nevertheless, as indicated by some other findings, the low frequency of such a strictly defined type is mainly due to the state of research. In most known enclosures, it is influenced by the size of the investigated area, the absence of traces of an entrance or unfavorable conditions for the preservation of remains of above-ground buildings and the identification of their appearances (more comments on this, e.g., in Trebsche 2009). This relatively narrow group can also be expanded by other cases which do not manifest such a high degree of regularity in the arrangement of buildings (fig. 7: 5-7, 9), but the disturbance of symmetry can only be seeming. The notion of existing buildings can be distorted by the research 
methods applied (e.g. the sites of Laibstadt: Berghausen 2014, 122-123, Abb. A14-15; Weiltingen: Berghausen 2014, 118-119, Abb. A8-9; Sallach 'groß': Hoffmann 2007 which were investigated geophysically). In several other sites, some of the ground plans may not have survived completely intact or could have been intentionally replaced by other types of architecture (e.g. Nordheim I: Neth 1997, 82, Abb. 42: F). Nevertheless, all the mentioned examples show a focus on an axial arrangement of buildings whose purpose was to highlight the importance of the often dimensionally and architecturally extraordinary structure standing opposite to the entrance to the enclosed area. The buildings in the Markvartice enclosure without doubt fit in the above examples. Also here, the axiality of the general architectural concept is quite obvious and symmetry is only disturbed by the absence of remains of a building in the northeastern corner. However, also in this case, this can only reflect the current state of knowledge. Numerous parallels in La Tène environments and the absence of traces of spatial arrangements which are to be expected in fortifications dating from later historical periods, ${ }^{9}$ allow us to definitely conclude the discussions about the chronological position of the Markvartice enclosure.

The occurrence of the discussed type of arrangement of the internal area in La Tène enclosures has so far only been identified in the territory of southern Germany, where it does not seem to form any specific, spatially delimited clusters. According to the current knowledge about its distribution, it is basically identical with the whole area of distribution of La Tène enclosures (fig. 8). The Markvartice buildings, which represent the first example of this type known from the territory of Bohemia, prove that it was a generally widespread phenomenon linked to all areas with the occurrence of the so-called Viereckschanzen. A common feature of both regions is not only the occurrence and formal resemblance of quadrangular enclosures, but also the way of arrangement of internal buildings, at least in some cases. It is likely that the concept both in Germany and Bohemia was based on similar or even identical formal rules which may have reflected the social status of related communities (Rieckhoff 2002, 366). It is, however, questionable whether such architecture was a bearer of identical ideas which cannot be satisfactorily answered due to the nature of available sources. The possibility that identical architectural types had been perceived differently in various cultural or geographical contexts was already discussed in the past (Trebsche 2009, 511, fig. 3). Certain clues in this sense can be sought in the close cultural interconnections between the two regions, which is also attested by other categories of finds during LT C2-D1. Links between the territory of Bohemia and regions situated further west are documented, for instance, by finds of Vindelician coins, some decorative fittings from wagons and harnesses, selected types of glass or metal jewellery or imported metal and ceramic vessels originating from the Tyrrhenian region (Wagner 2006; Pierrevelcin

\footnotetext{
${ }^{9}$ Comparisons of sources for the issue of establishing modern era military camps unambiguously point to efforts to efficiently use the enclosed area, with a focus on regularity, which is reflected in the division of camps into rectangularly surveyed streets (Straßburger 2014, 159; Andresová 2018, 143-144). Buildings in military camps usually consisted of tents of different sizes arranged in more or less regular rows. They, however, do not leave any archaeologically traceable remains. Only in several rare cases, tents were (partly) replaced by wooden barracks, usually of lighter construction (Osgood 2005, 119; Homann 2013, 209). Dwellings of soldiers were also often accompanied by various workshops and a large number of regularly spaced garbage and kitchen pits which were an integral part of camp life (Cosack 2006; Straßburger 2014, 159-161; Drnovský-Hejhal 2017, 47, fig. 7). It is the remains of such sunken features, also accompanied by traces of thermal alteration, that should be detected by magnetometry, provided the conditions are favourable.
} 


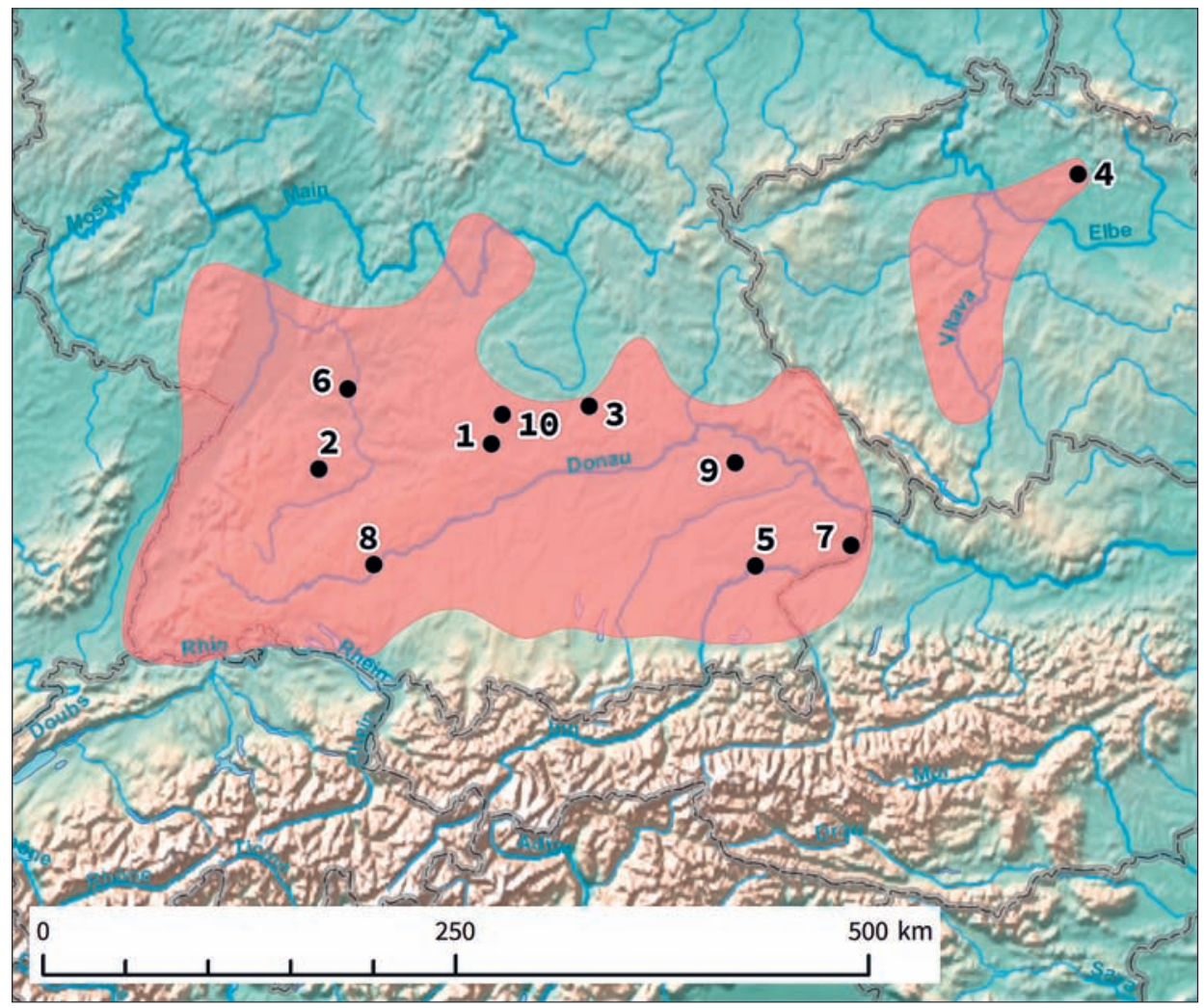

Fig. 8. Distribution of La Tène quadrangular enclosures with a significant building situated opposite the entrance. Areas of occurrence of La Tène quadrangular enclosures are marked in red. The area of occurrence of La Tène quadrangular enclosures according to Bittel - Schieck - Müller 1990, Abb. 9, modified.

Obr. 8. Rozšíření laténských čtyřúhelníkových valových areálů s význačnou stavbou umístěnou naproti vstupu. Červeně vyznačeny oblasti s výskytem laténských čtyřúhelníkových valových areálů. Oblast rozšíření čtyřúhelníkových valových areálů podle Bittel - Schieck - Müller 1990, Abb. 9, upraveno.

1 - Bopfingen-Flochberg, Lkr. Ostalbkreis; 2 - Ehningen, Lkr. Böblingen; 3 - Laibstadt, Lkr. Roth; 4 - Markvartice, Jičín district; 5 - Maxing, Lkr. Mühldorf am Inn; 6 - Nordheim I, Lkr. Heilbronn; 7 - Pocking-Hartkirchen, Lkr. Passau; 8 - Riedlingen, Lkr. Biberach; 9 - Sallach 'groß', Lkr. Straubing-Bogen; 10 - Weiltingen, Lkr. Ansbach.

2012; Kysela 2014; Militký 2015, 115, tab. 26; Venclová 2015, 164; Sievers 2015; Wendling 2015; Mangel - Jošková - Krásný 2019, 40-41, fig. 6). It is reasonable to suppose that the current rarity of this form of building development in the territory of Bohemia is, similarly to Germany, rather a result of the current state of knowledge than of regional differences in the cultural manifestations of the La Tène period.

\section{Conclusion}

The research activities conducted at Markvartice in 2018 resulted in findings crucial to the site itself as well as to the improvement of our knowledge about the arrangement of internal 
buildings in La Tène enclosures in Bohemia in general. Thanks to the application of areal geophysical measurements, remnants of horseshoe-shaped above-ground buildings following the course of the fortification lines were identified. Analogous ground plans of individual building structures and the general arrangement of the internal area were repeatedly, although not very often, documented in several La Tène enclosures in southern Germany. For the time being, Markvartice is the only example known from outside the territory of southern Germany. It seems to belong to a group of enclosures featuring a similar architectural concept which are designated as the Riedlingen type. The striking degree of similarity between them reveals that the arrangement of the internal space in La Tène enclosures was based on similar formal rules reflecting the social status of related communities in all territory of their distribution. It is still questionable whether such architecture in all this large territory was also a bearer of identical meanings.

The general frequency of so far known representatives of this narrowly defined conceptual type of enclosures is still relatively low. However, a gradual increase in their numbers shows that this state is not connected with cultural aspects but rather with the possibilities of understanding and the limitations of field research. An important role in this respect is played by the size of the investigated area, the frequent absence of unambiguous traces which would reveal the placement of the entrance or the limitations resulting from conditions for the preservation and identification of above-ground buildings. When trying to answer the questions connected with the organizational aspects of building structures within enclosures, it is necessary to strive for a complete exploration of their whole internal space. A suitable alternative to large areal excavations which are usually costly and difficult to implement are geophysical methods, despite certain drawbacks.

The article was created within the Project of Specific Research of the FF UHK 2019 called Non-destructive investigations of selected La Tène archaeological sites in eastern Bohemia.

English by Jan Machula

\section{References}

Ambs, R. 2011: Die keltische Viereckschanze bei Beuren, Marktgemeinde Pfaffenhofen an der Roth, Landkreis Neu-Ulm, Bayern. Berichte zur Archäologie im Landkreis Neu-Ulm und in den angrenzenden Gebieten 4. Neu-Ulm: Landkreis Neu-Ulm - Kreisarchäologie.

Andresová, K. 2018: Obraz raně novověkých vojenských táborů na stránkách dobových vojenských příruček. In: V. Matoušek - M. Sýkora eds., Válečné události 17.-19. století z interdisciplinární perspektivy, Praha: Togga, 135-173.

Auer, I. - Hees, M. - Stephan, E. - Steppan, K. 2018: Die Viereckschanzen von Nordheim. Zwei spätkeltische Gutshöfe im Neckarland. Denkmalpflege in Baden-Württemberg. Nachrichtenblatt der Landesdenkmalpflege 47, 113-118.

Berghausen, K. 2010: Magnetische Signale des Feuers - Prospektion an der spätkeltischen Viereckschanze von Laibstadt. Das archäologische Jahr in Bayern 2009, 80-83.

Berghausen, K. 2014: Magnetometrische Untersuchungen an spätkeltischen Viereckschanzen in Bayern. Inhalte - Projekte - Dokumentationen. Schriftenreihe des Bayerischen Landesamtes für Denkmalpflege 9. München: Volk Verlag München.

Bittel, K. - Schieck, S. - Müller, D. 1990: Die keltischen Viereckschanzen, Teil 1 - Text. Atlas archäologischer Geländedenkmäler in Baden-Württemberg 1/1. Stuttgart: Konrad Theiss Verlag.

Bollacher, Ch. 2009: Die keltische Viereckschanze „Auf der Klinge” bei Riedlingen. Materialhefte zur Archäologie in Baden-Württemberg 88. Stuttgart: Konrad Theiss Verlag. 
Budinský, P. 1986: Výzkumy a prírůstky archeologického odboru Krajského muzea v Teplicích $\vee$ letech 1972-1981. Archeologický výzkum v severních Čechách 13. Teplice: Krajské muzeum Teplice.

Cosack, E. 2006: Spuren eines Heerlagers vor den Toren von Sarstedt, Ldkr. Hildesheim. Nachrichten aus Niedersachsens Urgeschichte 75, 241-252.

Donat, P. 2006: Zu Hausbefunden aus Hallstatt- und Latènezeitlichen Viereckanlagen in Süddeutschland. Jahrbuch des Römisch-Germanischen Zentralmuzeums 53, 109-173.

Drnovský, P. - Hejhal, P. 2017: Krajina k boji odsouzená. Polní tábor pruského krále Fridricha II. ze srpna 1778 pohledem archeologie. Živá archeologie - Rekonstrukce a experiment $v$ archeologii 19, 42-51.

Faßbinder, J. 2005: Methodische Untersuchungen zur Magnetometerprospektion von Viereckschanzen. In: P. Neumann-Eisele ed., Viereckschanzen. Rätselhafte Bauwerke der Kelten. Stand der Viereckschanzenforschung in Bayern und Baden-Württemberg. Kolloquium Kelheim. Archäologisches Museum der Stadt Kelheim, Museumsheft 8, Kelheim: Archäologisches Museum der Stadt Kelheim, 11-22.

Faßbinder, J. - Irlinger, W. 2000: Magnetometerprospektion der spätkeltischen Viereckschanze von Maxing, Gemeinde Erharting, Landkreis Mühldorf a. Inn, Oberbayern. Das archäologische Jahr in Bayern 1999, 43-45.

Faßbinder, J. - Irlinger, W. 2005: Magnetometerprospektion einer spätkeltischen Viereckschanze bei Pfeffenhausen. Das archäologische Jahr in Bayern 2004, 76-78.

Foster, P. - Venclová, N. - Křvánek, R. 2004: Quadrangular enclosure at Rakovice (distr. Písek). In: M. Gojda ed., Ancient Landscape, Settlements Dynamics and Non-Destructive Archaeology, Praha: Academia, 249-265.

Haken, J. 1974: Markvartice u Sobotky. Zpravodaj Šrámkovy Sobotky XI/1-2, 18-21.

Hlásek, D. - Mašlová, K. - Křivánek, R. 2018: Nově objevená „Viereckschanze" u Stožic (okr. Strakonice). Archeologické výzkumy v jižních Čechách 31, 219-240.

Hoffmann, A. 2007: Untersuchungen zur prähistorischen Relief- und Bodengenese im Areal der spätlatènezeitlichen Viereckschanzen von Sallach, Lkr. Straubing-Bogen. Regensburger Beiträge zur Bodenkunde, Landschaftsökologie und Quartärforschung 13. Regensburg: Universität Regensburg.

Homann, A. 2013: Battlefield Archaeology of Central Europe - With a Focus on Early Modern Battlefields. In: N. Mehler ed., Historical Archaeology in Central Europe, Rockville, MD: Society for Historical Archaeology, 203-230.

Jansová, L. 1968: Mšecké Žehrovice und die Frage der Viereckschanzen in Böhmen. Archeologické rozhledy 20, 470-489.

John, J. 2018: Die Viereckschanzen in Böhmen - ein Überblick. Vorträge des 37. Niederbayerischen Archäologentages, 395-410.

Jošková, T. 2016: Valový objekt u Markvartic (okr. Jičín) ve světle analýz a archeologických poznatků. Manuscript of the master's thesis stored at the Philosophical Faculty UHK in Hradec Králové.

Korený, $R$. - Krušinová, L. - Křivánek, $R$. - Šimek, R. - Šimková, J. - Škácha, P. 2017: Viereckschanze a sídliště u Starosedlského Hrádku, okr. Př́bram. Výsledky průzkumu z let 2008-2012 a 2015. Archeologické výzkumy v jižních Čechách 30, 291-314.

Köhler, H.-J. 1992: Siedlungsbefunde und Bebauungsrekonstruktion. In: F. Maier et al., Ergebnisse der Ausgrabungen 1984-1987 in Manching. Die Ausgrabungen in Manching 15, Sttutgart: Franz Steiner Verlag, 5-64.

Krause, R. - Wieland, G. 1993: Eine keltische Viereckschanze bei Bopfingen am Westrand des Rieses. Germania 71, 59-112.

Kriviánek, R. 2004: Geofyzikální metody. In: M. Kuna a kol., Nedestruktivní archeologie, Praha: Academia, 117-183.

Křivánek, R. 2013: Geophysical surveys of abandoned quadrangular enclosures ("Viereckschanzen") from La Tène period in Bohemia. ISAP NEWS. The newsletter of the International Society for Archaeological Prospection 36, 5-7.

Křivánek, R. 2014a: Archeogeofyzikální průzkumy Archeologického ústavu AV ČR Praha v jižních Čechách v letech 2012-2013. Archeologické výzkumy v jižních Čechách 27, 371-382.

Křivánek, R. 2014b: Geofyzikální průzkumy na archeologických lokalitách ve východních Čechách, 20002011. Archeologie východních Čech 5, 205-226.

Kysela, J. 2014: Okruhy středomořského importu ve střední Evropě pozdní doby laténské. In: J. Čižmářová - N. Venclová - G. Březinová eds., Moravské křižovatky. Střední Podunají mezi pravěkem a historií, Brno: Moravské zemské muzeum, 229-242.

Laurelut, Ch. - Tegel, W. - Vanmorkerke, J. 2009: Neue Aspekte zur Architekturgeschichte von der späten Eisenzeit bis zum Beginn der Römerzeit in Ostfrankreich. In: P. Trebsche et al. eds., Architektur: Inter- 
pretation und Rekonstruktion: Beiträge zur Sitzung der AG Eisenzeit während des 6. Deutschen Archäologie-Kongresses in Mannheim 2008, Langenweissbach: Beier \& Beran, 79-95.

Leicht, M. 2013: Siedlungsbefunde und Bebauungsrekonstruktion. In: S. Sievers et al., Ergebnisse der Ausgrabungen in Manching-Altenfeld 1996-1999. Die Ausgrabungen in Manching 18, Wiesbaden: Reichert Verlag, 17-117.

Mangel, T. - Jošková, T. - Krásný, F. 2019: Nález laténského vodícího kroužku z Markvartic v kontextu obdobných nálezů z Čech a Moravy. Študijné zvesti Archeologického ústavu SAV 66, 33-48.

Martínek, J. - Létal, A. - Peška, J. - Kalábek, M. - Vrána, J. - Šlézar, P. 2013: Identifikace starých cest a dalších objektů za pomoci LLS. In: M. Gojda - J. John et al., Archeologie a letecké laserové skenování krajiny, Plzeň: Západočeská univerzita v Plzni, 227-239.

Mecking, A. 2017: Das latènezeitliche Gehöft und sein Haus. In: R. Karl - J. Leskovar eds., Interpretierte Eisenzeiten. Fallstudien, Methoden, Theorie. Tagungsbeiträge der 7. Linzer Gespräche zur interpretativen Eisenzeitarchäologie. Studien zur Kulturgeschichte von Oberösterreich 47, Linz: Oberösterreichisches Landesmuseum, 121-140.

Mecking, A. 2018: Wahre Größe kommt von innen... Einige Bemerkungen zur Innenbebauung jüngerlatènezeitlicher Wall-Graben-Anlagen aus Süddeutschland. In: S. Wefers et al. eds., KunstHandWerk. Beiträge der 26. Tagung der AG Eisenzeit gemeinsam mit der Keltenwelt am Glauberg und der hessen ARCHÄOLOGIE im Landesamt für Denkmalpflege Hessen in Bad Salzhausen - 3.-6. Oktober 2013. Beiträge zur Ur- und Frühgeschichte Mitteleuropas 84, Langenweissbach: Beier \& Beran. Archäologische Fachliteratur, 177-191.

Meduna, P. 1990: Morphology of field fortifications of the 17th-19th centuries. A contribution to surface research. In: Z. Smetánka - J. Žegklitz eds., Studies in Postmedieval Archaeology 1, Praha: Institute of Archaeology of the Academy of Sciences of the Czech Republic, 75-86.

Militký, J. 2015: Oppidum Hradiště u Stradonic. Komentovaný katalog mincovních nálezů a dokladů mincovní výroby. Praha: Abalon - Archeologický ústav AV ČR.

Möslein, S. 2003: Spätkeltische Umgangsbauten von Straubing-Lerchenhaid. Vorträge des 21. Niederbayerischen Archäologentages, 93-131.

Neth, A. 1997: Zum Abschluss der Grabungen in der keltischen Viereckschanze bei Nordheim, Kreis Heilbronn. In: Archäologische Ausgrabungen in Baden-Württemberg 1996, Stuttgart: Konrad Theiss Verlag, 79-85.

Neth, A. 2001: Zum Abschluss der Ausgrabungen in der zweiten Viereckschanze bei Nordheim, Kreis Heilbronn. In: Archäologische Ausgrabungen in Baden-Württemberg 2000, Stuttgart: Konrad Theiss Verlag, 80-84.

Osgood, R. 2005: The unknown warrior. An archaeology of the common soldier. Stroud: Sutton Publishing.

Pažout, J. 1927: Hradiště u M. Lhoty, Vesce, Markvartic, Važic a Psinic a jejich význam. Náš domov: vlastivědný sborník okresů Jičín - Libáň - Sobotka 1 (1925-1926), 26-28, 54-59.

Pierrevelcin, G. 2012: Les relations entre la Bohême et la Gaule du IVe au ler siècle avant J.-C. Dissertationes archaeologicae Brunenses/Pragensesque 12. Praha: Filozofická fakulta Univerzity Karlovy v Praze.

Píč, J. L. 1909: Čechy za doby knížecí. Starožitnosti země České III/1. Praha: Museum království Českého.

Reichenberger, A. 1986: Ausgrabungen in einer Viereckschanze bei Arnstorf-Wiedmais, Landkreis Rottal-Inn, Niederbayern. Das archäologische Jahr in Bayern 1985, 88-90.

Reichenberger, A. 1993a: Zur Interpretation der Spätkeltischen Viereckschanzen. Jahrbuch des RömischGermanischen Zentralmuseums Mainz 40, 353-396.

Reichenberger, A. 1993b: Bemerkungen zur Herleitung und Entstehung der spätkeltischen Viereckschanzen. Acta Praehistorica et Archaeologica 25, 186-210.

Reichenberger, A. 1995: Zu hölzernen Umgangsbauten in der Latènezeit. In: K. Schmotz - M. Zápotocká eds., Archäologische Arbeitsgemeinschaft Ostbayern/West- und Südböhmen. 4. Treffen 15. bis 18. Juni 1994 in Mariánská Týnice, Espelkamp: Verlag Marie L. Leidorf, 72-86.

Reichenberger, A. - Schaich, M. 1996: Vorbericht zur Ausgrabung der Viereckschanze von Platting-Pankofen, Lkr. Deggendorf. Vorträge des 14. Niederbayerischen Archäologentages, 83-153.

Rieckhoff, S. 2002: Der Untergang der Städte. Der Zusammenbruch des keltischen Wirtschafts- und Gesellschaftssystems. In: C. Dobiat - S. Sievers - T. Stöllner eds., Dürrnberg und Manching. Wirtschaftsarchäologie im ostkeltischen Raum. Akten des internationalen Kolloquiums in Hallein/Bad Dürrnberg vom 7. bis 11. Oktober 1998, Bonn: Dr. Rudolf Habelt GmbH, 359-379.

Schaich, M. 1998: Zur Ausgrabung der Viereckschanze von Pocking-Hartkirchen, Lkr. Passau. Vorträge des 16. Niederbayerischen Archäologentages, 157-191. 
Schaich, M. 2001: Zur Rekonstruktion der Bebauung spätkeltischer Viereckschanzen. In: K. Schmotz ed., Archäologische Arbeitsgemeinschaft Ostbayern/West- und Südböhmen, 10. Treffen, 7. bis 10 Juni 2000 in Český Krumlov, Rahden/Westf.: Verlag Marie Leidorf GmbH, 121-147.

Schaich, M. 2002: Niederbayerische Viereckschanzen. Fortschritte der Forschung. Vorträge des 20. Niederbayerischen Archäologentages, 331-352.

Schaller, J. 1786: Topographie des Königreichs Böhmen - vierter Teil. Bunzlauer Kreis. Prag: K. K. Normalbuchdruckerer, durch Wenzel Piskaczek.

Schiek, S. 1985: Eine neue keltische Viereckschanze bei Ehningen, Kreiss Böblingen. Archäologische Ausgrabungen in Baden-Württemberg 1984, 78-82.

Schubert, F. 1995: Keltische Umgangstempel von Ingolstadt-Zuchering?. In: K. H. Rieder - A. Tillmann eds., Archäologie um Ingolstadt. Die archäologischen Untersuchungen beim Bau der B 16 und der Bahnverlegung, Kipfenberg: Hercynia Verlag, 127-85.

Schwarz, K. 1960: Spätkeltische Viereckschanzen. Ergebnisse der topographischen Vermessung und der Ausgrabungen 1957-1959. Jahresbericht der Bayerischen Bodendenkmalpflege 1, 7-41.

Sievers, S. 2015: Boier in Bayern?. In: M. Karwowski - V. Salač - S. Sievers eds., Boier zwischen Realität und Fiktion, Akten des internationalen Kolloquiums in Český Krumlov vom 14.-16. 11. 2013. Kolloquien zur Vor- und Frühgeschichte 21, Bonn: Dr. Rudolf Habelt GmbH, 375-383.

Stork, I. 1999: Zum Abschluß der Ausgrabungen in der Viereckschanze von Blaufelden, Kreis Schwäbisch Hall. Archäologische Ausgrabungen in Baden-Württemberg 1998, 115-120.

Stöckli, W. E. 2018: Spätlatènezeitliche Germanen in Süddeutschland. Archäologische Informationen 41, 199-238.

Straßburger, M. 2014: Leben im Lager - materielle Hinterlassenschaften militärischer Gesellschaften der frühen Neuzeit. In: S. Eickhoff - F. Schopper eds., Schlachtfeld und Massengrab: Spektren interdisziplinärer Auswertung von Orten der Gewalt, Fachtagung vom 21. bis 24. November 2011 in Brandenburg an der Havel, Forschungen zur Archäologie im Land Brandenburg 15, Wünsdorf: Brandenburgisches Landesamt für Denkmalpflege und Archäologisches Landesmuseum, 145-168.

Šalda, F. 1955: Český ráj. Jičínsko - Sobotecko. Oblastní turistický průvodce. Praha: STN.

Šalda, F. 1969: Vlastivěda jičínska. Jičín: Okresní pedagogické středisko v Jičíně.

Šámal, Z. 2011: Archeologové na bojišti (Několik poznámek k detektorovému průzkumu rakovnického bojiště z roku 1620). In: K. Blažková ed., Bitva u Rakovníka 1620, Rakovník - Chráštany: Muzeum T. G. M. Rakovník - Agroscience spol. s r. 0., 50-59.

Šulc, V. 1966: K průzkumu starých sídlišt' na Sobotecku. Zpravodaj Šrámkovy Sobotky III/11, 12-13.

Trebsche, P. 2009: Does Form Follow Function? Towards a Methodical Interpretation of Archaeological Building Features. World Archaeology 41, 505-519.

Ulrychová, E. 2000: Archeologické nálezy z Markvartic. Muzejní noviny 17, 6.

Ulrychová, E. 2010: Novověké vojenské tábory na jičínsku. In: E. Macková ed., Polní opevnění od třicetileté války do roku 1945. Sborník Národního památkového ústavu, územního odborného pracoviště v Josefově, Jaroměř - Josefov: Národní památkový ústav, územní odborné pracoviště v Josefově, 23-32.

Venclová, N. 1998: Mšecké Žehrovice in Bohemia. Archaeological Background to a Celtic Hero, $3^{\text {rd }}-2^{\text {nd }}$ century B. C. Sceaux: Kronos B. Y. Editions.

Venclová, N. 1999: Mšecké Žehrovice (Bez. Rakovník/Mittelböhmen, Tschechische Republic). In: G. Wieland ed., Keltische Viereckschanzen. Einem Rätsel auf der Spur, Stuttgart: Konrad Theiss Verlag, 202-205.

Venclová, N. 2000: Dvorce a druidové. In: I. Pavlů ed., In memoriam Jan Rulf. Památky archeologické - Supplementum 13, Praha: Archeologický ústav AV ČR, 458-471.

Venclová, N. 2006: Enclosing, enclosures and elites in the Iron Age. In: A. Harding - S. Sievers - N. Venclová eds., Enclosing the past: inside and outside in prehistory. Sheffield Archaeological Monographs 15, Sheffield: J. R. Collis Publications, 140-154.

Venclová, N. 2015: Bohemia and markers of La Tène communities in the Middle Danube region. In: M. Karwowski - V. Salač - S. Sievers eds., Boier zwischen Realität und Fiktion. Akten des internationalen Kolloquiums in Český Krumlov vom 14.-16. 11. 2013. Kolloquien zur Vor- und Frühgeschichte 21. Bonn: Dr. Rudolf Habelt GmbH, 159-167.

Venclová, N. ed. 2008: Archeologie pravěkých Čech 7. Doba laténská. Praha: Archeologický ústav AV ČR.

Vokolek, V. 1982: Markvartice, okr. Jičín. In: Výzkumy v Čechách 1978-79, Praha: Archeologický ústav ČSAV, 71.

Vokolek, V. 1993: Počátky osídlení východních Čech. Hradec Králové: Muzeum východních Čech.

Vokolek, V. - Sigl, J. 1978: Markvartice, okr. Jičín, „Na Šancích“. Manuscript of the field report stored at the Archaeological Department of the Museum of Eastern Bohemia in Hradec Králové. 
Vokolek, V. - Sigl, J. 1979: Záchranné výzkumy a jiné akce v terénu provedené v roce 1978. Zpravodaj Krajského muzea východních Čech v Hradci Králové 6, 3-10.

Wagner, H. 2006: Glasschmuck der Mittel- und Spätlatènezeit am Oberrhein. Ausgrabungen und Forschungen 1. Remshalden: Verlag Bernhard Albert Greiner.

Waldhauser, J. 1970: Problém tzv. Viereckschanzen (keltských čtyřúhelníkových valů) a nově zjištěné oppidum v severních Čechách. Archeologické rozhledy 22, 327-334.

Waldhauser, J. 1970-1971: Výzkum čtyřúhelníkových valů a laténského sídliště u Markvartic (o. Jičín) v roce 1969. Sborník Československé společnosti archeologické při ČSAV 4, 61-88.

Waldhauser, J. 1972a: Geofyzikální měření odporu půdy v areálu keltské svatyně u Markvartic. Zpravodaj Šrámkovy Sobotky IX/1-2, 37.

Waldhauser, J. 1972b: Archeologický výzkum keltské svatyně u Markvartic v roce 1972. Zpravodaj Šrámkovy Sobotky IX/1-2, 86.

Waldhauser, J 1975: Die keltischen Viereckschanzen in Böhmen. Alba Regia 14, 235-244.

Waldhauser, J. 1978: Markvartice, okr. Jičín. In: Výzkumy v Čechách 1975, Praha: Archeologický ústav ČSAV, 51.

Waldhauser, J. 1979: Beitrag zum Studium der keltischen Siedlungen, Oppida und Gräberfelder in Böhmen. In: P.-M. Duval - V. Kruta eds., Les mouvements celtiques du Ve au ler siècle avant notre ère. Actes du $18^{\mathrm{e}}$ colloque organisé a l'occasion du $9^{\mathrm{e}}$ Congres international des sciences préhistoriques et protohistoriques, Nice, le 19 septembre 1976, Paris: Centre National de la Recherche Scientifique, 117-156.

Waldhauser, J. 1989: Etat de la recherche sur les enceintes quadrilatérales laténiennes (dites Viereckschanzen) en Bohème. In: O. Buchsenschutz - L. Olivier eds., Les Viereckschanzen et les enceintes quadrilaterales en Europe Celtique, Paris: Editions Errance, 43-55.

Waldhauser, J. 1992: Problém identifikace keltských čtyřúhelníkových valů (Viereckschanzen) v Čechách. Archeologické rozhledy 44, 548-559.

Waldhauser, J. 1999: Markvartice (Bez. Jičín/Böhmen, Tschechische Republic). In: G. Wieland ed., Keltische Viereckschanzen. Einem Rätsel auf der Spur, Stuttgart: Konrad Theiss Verlag, 206-208.

Waldhauser, J. 2003: Stojí u Markvartic památka po Keltech nebo vojenský tábor Švédů?. Muzejní noviny 23, $18-19$.

Waldhauser, J. - Smejtek, L. - Nováček, K. 1989: Montánní archeologický výzkum na lokalitě Třebsko na Př́ibramsku. Studie z dějin hornictví 22, 1-36.

Wendling, H. 2015: Die Helvetier als Nachbarn der Boier - Kommunikation und Vernetzung gallischer und ostkeltischer Räume. In: M. Karwowski - V. Salač - S. Sievers eds., Boier zwischen Realität und Fiktion. Akten des internationalen Kolloquiums in Český Krumlov vom 14.-16. 11. 2013. Kolloquien zur Vorund Frühgeschichte 21, Bonn: Dr. Rudolf Habelt GmbH, 391-409.

Wieland, G. 1995: Die Spätkeltischen Viereckschanzen in Süddeutschland - Kultanlagen oder Rechteckhöfe?. In: A. Haffner ed., Heiligtümer und Opferkulte der Kelten, Sttutgart: Konrad Theiss Verlag, 85-99.

Wieland, G. 1999a: Kultische und profane Funkcionaspekte. In: G. Wieland ed., Keltische Viereckschanzen. Einem Rätsel auf der Spur, Stuttgart: Konrad Theiss Verlag, 73-80.

Wieland, G. 1999b: Bauten in Viereckschanzen. In: G. Wieland ed., Keltische Viereckschanzen. Einem Rätsel auf der Spur, Stuttgart: Konrad Theiss Verlag, 34-53.

Wieland, G. 1999c: Donnersberg bei Kirchhembolanden (Rheinland-Pfalz). In: G. Wieland ed., Keltische Viereckschanzen. Einem Rätsel auf der Spur, Stuttgart: Konrad Theiss Verlag, 199-201.

Wieland, G. - von der Osten-Woldenburg, H. - Wahl, J. 1999: Untersuchungen in der spätkeltischen Viereckschanzene „Am Scheerer Weg" bei Mengen-Ennetach, Kreis Sigmaringen. Archäologische Ausgrabungen in Baden-Württemberg 1998, 125-133.

TOMÁŠ MANGEL, Department of Archaeology, Philosophical Faculty, University of Hradec Králové, Rokitanského 62, CZ-500 03 Hradec Králové III; tomas.mangel@uhk.cz

TEREZA JOŠKOVÁ, Department of Archaeology, Philosophical Faculty, University of Hradec Králové,

Rokitanského 62, CZ-500 03 Hradec Králové III; tereza.joskova@uhk.cz

PETER MILO, Department of Archaeology and Museology, Faculty of Arts, Masaryk University, Arna Nováka 1, CZ-60200 Brno; 101090@mail.muni.cZ

TOMÁŠ TENCER, Department of Archaeology and Museology, Faculty of Arts, Masaryk University, Arna

Nováka 1, CZ-602 00 Brno; tencer@mail.muni.cz 